GEORGIA JOURNAL OF INTERNATIONAL AND COMPARATIVE LAW

VOLUME 40

2012

NUMBER 2

\title{
ARTICLES
}

\section{THE Evolution OF THE COMMON LAW AND EFFICIENCY*}

\author{
Nuno Garoupa** \& Carlos Gómez Ligüerre ${ }^{* * *}$
}

TABLE OF CONTENTS

I. INTRODUCTION

A. Development of the Common Law........................................... 311

B. Local Determinants of the Common Law and Legal Origins... 313

C. The Role of Statute Law.............................................................316

D. Choice of Common Law Jurisdictions...................................... 318

II. THE EFFICIENCY OF THE COMMON LAW HYPOTHESIS ....................319

A. Multiple Efficient Equilibria .................................................322

B. Single Efficient Equilibrium ...................................................... 323

C. Putting Both Models Together ................................................ 325

\footnotetext{
* The authors are grateful to Daniel Berkowitz, Donald J. Boudreaux, Henry Butler, Peter Cane, Tony Duggan, Anna Ginès Fabrellas, Anthony Ogus, Ken Oliphant, Paul Rubin, Mathias Siems, Greg Taylor, Andrew Torrance, Catherine Valcke, Stephen Waddams, the Searle-Kauffman (2009-2010) fellows at the Orange County meeting, and the participants at the Spanish Association of Law and Economics meeting (Madrid, 2010) for helpful comments and suggestions. This project was completed while Nuno Garoupa was visiting Universitat Pompeu Fabra. Financial support by the Generalitat of Catalunya (Agència de Gestió d'Ajuts Universitaris i de Recerca) is gratefully acknowledged. Roya H. Samarghandi and Caroline Belloff have provided superb research assistance. The usual disclaimers apply.

${ }^{* *}$ Professor, H. Ross and Helen Workman Research Scholar and Co-Director of the Illinois Program on Law, Behavior and Social Science, UIUC College of Law; B.A. Econ., Universidade Nova de Lisboa (Portugal); M.S.c. Econ., University of London (United Kingdom); D.Phil. Econ., University of York (United Kingdom); LLM, University of London (United Kingdom).

*** Associate Professor of Private Law, Universitat Pompeu Fabra (Spain); B.A. Management, LLB, Ph.D. Law Universitat Pompeu Fabra (Spain).
} 


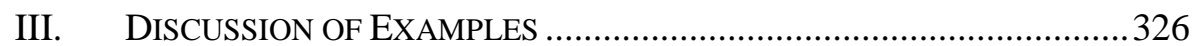

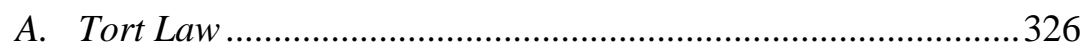

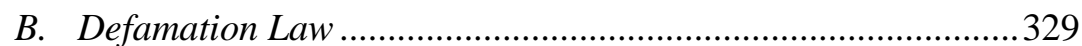

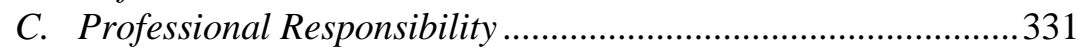

D. Cost Rules in Civil Litigation ................................................... 332

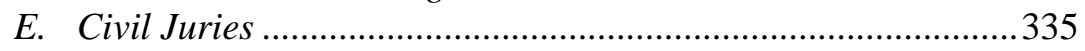

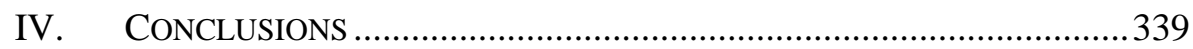




\section{INTRODUCTION}

The efficiency of the common law generated discussion among legal economists quite early in the law and economics literature. The controversial thesis was introduced by Judge Richard Posner in his seminal book, Economic Analysis of Law. ${ }^{1}$ His main argument was that there is an implicit economic logic to the common law. ${ }^{2}$ In his view, the doctrines in common law provide a coherent and consistent system of incentives which induce efficient behavior, not merely in explicit markets, but in all social contexts (the so-called implicit markets). ${ }^{3}$ For example, common law reduces transaction costs to favor market transactions when appropriate. ${ }^{4}$ Quite naturally, Judge Posner recognizes that not all doctrines in common law are economically justifiable or even easy to understand from an economic perspective. ${ }^{5}$ Economics does not offer a complete and exhaustive theory of the common law, but his view is that it offers a balanced and significant explanation. ${ }^{6}$

Judge Posner's hypothesis can be traced back to the evolutionary theory of the common law suggested by Justice Holmes in the 1880s. ${ }^{7}$ Holmes's main argument was that the judicial responses to public policy, rather than some internal logic, drive development of the common law. ${ }^{8}$ According to him, the ability of the common law to adjust appropriately to external needs relied on the recruitment of the judiciary as representatives of the community. ${ }^{9}$ Notably, Holmes's theory vehemently opposed the codification movement in the United States in those days. ${ }^{10}$ Justice Holmes did not use an efficiency argument for the common law (and against codification). ${ }^{11}$ Although developed in a different historical background, Judge Posner's understanding of the common law is not very different from the theory developed by Justice Holmes.

It is important to stress that the common law of Justice Holmes and Judge Posner reflects the Blackstonian definition. According to Sir William

\footnotetext{
${ }^{1}$ Richard Posner, ECONOMIC ANALysis of LAW (8th ed. 2011).

2 Id. at 315.

3 Id. at 315-20.

${ }^{4}$ Id. at 315; see Anthony Niblett et al., The Evolution of a Legal Rule, 39 J. LEGAL STUD. 325 (2010) (discussing application of empirical testing of common law in commercial areas converging to efficiency).

${ }^{5}$ POSNER, supra note 1 , at 320.

${ }^{6}$ Id.

${ }^{7}$ Oliver Wendell Holmes, JR., The Common LaW (1891).

${ }^{8}$ Id.

${ }^{9} \mathrm{Id}$.

10 Sheldon M. Novick, Introduction, in Oliver Wendell Holmes, JR., The Common LaW (1991).

${ }^{11}$ Id.
} 
Blackstone, writing in 1796, the common law consists of general customs by which the judges and the courts are guided and directed. ${ }^{12}$ Alternatively, the common law includes all legal doctrines that do not require a written form to be valid but rather rely on the usage by courts. ${ }^{13}$ Therefore, statutes have a secondary and subordinate role. ${ }^{14}$ They are essentially declaratory (to restate the common law) or remedial (to correct the flaws of the common law) ${ }^{15}$

However, in American legal history, the Blackstonian understanding of the common law has not been without controversies. For example, Justice Cardozo saw clear advantages in the codification process and recognized some advantages to the French legal method in shaping judgments. ${ }^{16}$ "The American codification debate in the nineteenth century clearly shows that there are multiple understandings of the role of the common law." ${ }^{17} \mathrm{By}$ proposing the efficiency hypothesis of the common law, Judge Posner noticeably opts for one side of the discussion. Unfortunately, most legal economists have not realized that the Posnerian hypothesis has to be understood in the context of a richer debate. ${ }^{18}$ Looking at the debates in the past, the traditional arguments for the Blackstonian common law included flexibility, stability, and ability to develop better rules without the need for statutes. ${ }^{19}$ The conventional arguments against the Blackstonian common law mentioned uncertainty (because of conflicting precedents), difficulty of nonlawyers to understand the law (higher transaction costs in modern economic language), and incorrectly allowing judges to legislate. ${ }^{20}$

\footnotetext{
12 The Commentaries of Sir William Blackstone, Knight, on the Laws and CONSTITUTION OF ENGLAND 1 (A.B.A., 2009).

${ }^{13}$ Id.

14 Id. at 8.

15 Id.

16 Benjamin N. Cardozo, The Nature of the Judicial Process 143 (9th ed. 1937) ("No doubt the ideal system ... . would be a code at once so flexible and so minute, as to supply in advance for every conceivable situation the just and fitting rule.”).

${ }^{17}$ Nuno Garoupa \& Carlos Gómez Ligüerre, The Syndrome of the Efficiency of the Common Law, 29 B.U. INT’L L.J. 287, 293-94 (2011).

${ }^{18}$ See David S. Clark, Development of Comparative Law in the United States, in THE OXFoRd HANDBOOK OF COMPARATIVE LAW 175, 175-215 (Mathias Reimann \& Reinhard Zimmermann eds., 2006), for a more detailed discussion about the influence of civil law in the United States. See generally Andrew P. Morriss, Codification and Right Answers, 74 CHI.KENT L. REV. 355 (1999) (noting the debate surrounding codification of American law in the nineteenth century).

19 See Morriss, supra note 18, at 376-77 (explaining that "code opponents argued that the common law was elastic and flexible and so could adapt itself to new circumstances" and "[i]ndeed, code opponents also claimed that the common law was simultaneously more stable as well as more elastic than statutes").

${ }^{20}$ Id. at 369.
} 
Still,

Judge Posner's hypothesis of the efficiency of the common law begs for a more detailed explanation from the start. In particular, the hypothesis lacks a more explicit [and consistent] mechanism for explaining why the common law should be efficient.... [A] remarkable literature emerged as a consequence. Legal economists proposed different [and ingenious] explanations that have been evolutionary models identifying the forces that have shaped the common law to generate efficient rules. ${ }^{21}$

"[I]f the common law is evolutionarily efficient, we are left with no explanation for the important doctrinal differences across common law jurisdictions ...."22 One of the many problems with the economic literature on this topic is the confusing use of "common law" to describe different legal features. Our definition is the standard one: "a body of general rules prescribing social conduct,” originally enforced by the ordinary royal courts in England (as opposed to equity, local, or ecclesiastical courts), and characterized by the development of its own principles in actual legal controversies (through the use of judicial precedents), by the procedure of trial by jury, and by the doctrine of the supremacy of law (all agencies of government are subject to court review and compelled to follow legal procedure such as due process). ${ }^{23}$

\section{A. Development of the Common Law}

The development of the common law in the thirteen colonies followed different paths that were not only distinct from the original English common law, but also between the colonies themselves. ${ }^{24}$ Unlike in the English tradition, colonial law tended to be codified with the exception of Maryland. $^{25}$ Some of these colonial law codes departed significantly from the English common law, in particular in New England (Massachusetts most importantly) and Pennsylvania. ${ }^{26}$ In other cases, such as Virginia and the

${ }^{21}$ Garoupa \& Ligüerre, supra note 17, at 294 (internal citations omitted). See generally Paul H. Rubin, Micro and Macro Legal Efficiency: Supply and Demand, 13 SuP. CT. ECON. REv. 19, 21-27 (2005) (providing an example of the evolutionary models as applied to common law). Explanations are discussed in detail in the following pages of this Article. See infra notes 77-79.

22 Garoupa \& Ligüerre, supra note 17, at 296.

23 Arthur R. Hogue, Origins of the Common Law 178-79 (1966).

24 Paul Samule Reinsch, English Common Law in the Early American Colonies 9 (1899).

${ }^{25}$ Id. at 53.

${ }^{26}$ Nevertheless, there were standard provisions to ensure that colonial law would not be radically in conflict with English common law. Id. 
Carolinas, English law was influential in adjudication, for example, but subsidiary to colonial law. ${ }^{27}$ In a show of the general respect for self rule, appeals from colonial courts to the English Privy Council were generally not allowed and drastically discouraged. ${ }^{28}$ Thus, it was not English common law, but these local departures that shaped the general reasoning and principles of American common law. ${ }^{29}$

All the same, it is unquestionable that the English common law influenced and formed the American common law. ${ }^{30}$ No doubt there were political and economic factors helping the convergence with English law. ${ }^{31}$ But the very different realities faced by the colonies and the metropolis led to significant departures from the English common law in many fields of law, notably property (including inheritance, alienability, and trespass), contracts (including remedies and restitution), torts (from negligence rules to proximate causation), slavery laws, and family (marriage and divorce rules). ${ }^{32}$

In fact, we could describe the early stages of American common law more accurately by recognizing the existence of thirteen different legal systems with different degrees of codification (quite significant in Massachusetts due to the Puritan distrust of lawyers). ${ }^{33}$ English law was important more in the sense of providing a background and legal method than the elements of substantive law. ${ }^{34}$ The situation changed in the eighteenth century, when colonial courts became more English in nature. ${ }^{35}$ The British developed more interventionist methods of governing the colonies, which resulted in a strengthening of the executive power. ${ }^{36}$ Although the British did not opt for a model of giving the courts in London jurisdiction over colonial courts, the role of the Privy Council was enhanced. $^{37}$ Colonial statute law was subject to review by the Privy

${ }^{28}$ But see Mary Sarah Bilder, The Transatlantic Constitution (2004) (describing Rhode Island's struggle to prevent the private appeal to the Privy Council).

${ }^{29}$ REINSCH, supra note 24 (noting that the circumstances of the colonies influenced them to depart from English common law); LaWrence M. Friedman, A History of American LAW (2005).

30 John H. LANGBEIN ET AL., History of THE COMMON LAW 874 (2009).

31 Id. at 878.

32 See id. at 873-921 (cataloging the differences between the English and American common law by subject).

${ }^{33}$ FrIEDMAN, supra note 29. Many colonial statutes have not been studied by modern legal historians because they have disappeared. See, for example, the recent discovery of the Laws and Liberties of Massachusetts from 1648.

${ }^{34} \mathrm{Id}$.

${ }^{35}$ Id.

${ }^{36} I d$.

${ }^{37}$ Id.
} 
Council. ${ }^{38}$ A process of convergence in substance and style was imposed by the Privy Council. ${ }^{39}$ Yet frequent delays and the permissive attitude of the Council (more political than truly judicial) undermined the possibility of full conformity of the colonial courts by the time of independence. ${ }^{40}$

Similar trends are found in other common law jurisdictions, such as Australia, Canada, New Zealand, and Ireland. ${ }^{41}$ Their common law systems have been formed and shaped by the English common law. Yet local determinants and different historical events have effected important departures from the original law in significant areas. ${ }^{42}$

\section{B. Local Determinants of the Common Law and Legal Origins}

This Article assesses the efficiency of the common law hypothesis to detect the possible explanations for those main differences. If local determinants shape the common law differently, the literature needs to address these particularities that have been largely ignored. The consequence is that there might be no single efficient outcome, thus undermining the "one-size-fits-all" theory of the legal origins literature. ${ }^{43}$ Alternatively, it could be the case that the common law only converges to efficiency under some conditions that could be undermined by specific local determinants.

In a different paper, we have already criticized the one-size-fits-all theory proposed by the legal origins literature. ${ }^{44}$ In that paper, we have provided a methodological critique of recent work by legal economists that emphasizes the superiority of the common law system over French civil law. We argued there that such an approach was based on a selected "cherry-picking” of legal doctrines and macro-generalizations that lack a serious theoretical framework. ${ }^{45}$ In that article, we articulated our skepticism concerning the

38 Id.

39 Id.

40 Id.

${ }^{41}$ See Hogue, supra note 23, at 235 (explaining that the common law is the root of the legal systems in all past British colonies).

42 See Matthew Hale, The History of the Common Law of England 114-21 (2d ed. 1716) (detailing the specific divergence of the Irish common law from that of the English).

43 See Paul G. Mahoney, The Common Law and Economic Growth: Hayek Might Be Right, 30 J. LEGAL STUD. 503, 504-05 (2001) (positing that the common law creates quicker growth because of stronger property and contract rights. The most critical claim is against French law since other civil law systems-German and Scandinavian-perform at least as well as common law); see also Rafael La Porta et al., The Economic Consequences of Legal Origins, 46 J. ECON. LiterAture 285, 326-27 (2008) (explaining the theory of legal origins). See generally Gani Aldashev, Legal Institutions, Political Economy, and Development, 25 OXFORD REv. ECON. POL’y 257 (2009) (surveying different legal origins research).

${ }^{44}$ Garoupa \& Ligüerre, supra note 17 , at 288.

${ }^{45} I d$. 
possibility of a sophisticated theory to sustain the superiority of the common law legal family. ${ }^{46}$

This Article reinforces our skepticism. It seems clear that the common law adjusts to local determinants that vary across the world, therefore producing different doctrines and legal outcomes. This argument contributes by further casting doubt on the selected cherry-picking methodology of the legal origins literature and the corresponding macro-generalizations. If the common law of a certain field, such as property or contracts, produces significantly different doctrines depending on local determinants, it is unclear which cherry-picked doctrine is being used to distinguish the common law from other legal families. A light version of the one-size-fitsall theory could suggest that not all rules across common law jurisdictions are actually efficient. Rather, the legal origins literature proposes that the model for creating rules (but not the substantive laws) is the same across common jurisdictions and more efficient than alternative methods (even if the substantive rules may turn out to be very different looking). The problem with this version is, as we show, the indeterminacy of the outcome. The empirical analysis employed by the one-size-fits-all theory focuses on the rules and doctrines, not the mechanisms.

In our work, we look primarily to the area of torts because the differences across common law jurisdictions have been widely perceived to be relevant to determine economic efficiency (even if it is unclear that tort law in particular actually increases the efficiency of the law). ${ }^{47}$ Quite importantly, we want to focus on asymmetric developments of the common law based on case law, rather than those imposed by statute law. For example, there are significant differences in the way common law jurisdictions treat class or group litigation. However, many of these differences are explained by statute law in the United States, ${ }^{48}$ Australia, ${ }^{49}$ England and Wales, ${ }^{50}$ and Canada, ${ }^{51}$ notwithstanding the significant influence of judge-made law. ${ }^{52} \mathrm{~A}$

${ }^{46}$ Id. at 289.

47 See, e.g., Yoram Barzel, Dispute and Its Resolution: Delineating the Economic Role of the Common Law, 2 Am. L. \& ECON. REv. 238 (2000) (arguing the efficiency of common law in contracts and property, but not in torts).

${ }^{48}$ Fed. R. Civ. P. 23.

49 Federal Court of Australia Act 1976 (Cth) pt IV(a) (Austl.). This part came into force by the passage of the Federal Court of Australia Amendment Act 1991 (Cth) s 3 (Austl.).

${ }^{50}$ Civil Procedure Rules, 1998, S.I. 1998/3132, R. 19-19.15 (U.K.).

51 Class Proceedings Act, S.O. 1992, c. 6 (Can.); Class Proceedings Act 1996, R.S.B.C. 1996, c. 50 (Can.); Class Actions Act, S.N.L. 2001, C-18.1 (Can.); Class Actions Act, S.S. 2001, c. C-12.01 (Can.); Class Proceedings Act, S.M. 2002, c. 14 (Can.); Class Proceedings Act, S.A. 2003, c. C-16.5 (Can.).

52 The English case law concerning the application of civil procedure rules to group litigation was influential, among others, in Australian and Canadian statute law going back to the Supreme Court of Judicature Act 1873. The role of the English Court of Appeal in 
similar remark can be made in the context of the common law presumption of individual rights, with Australia being the outstanding exception, ${ }^{53}$ while the United Kingdom, ${ }^{54}$ United States, ${ }^{55}$ Canada, ${ }^{56}$ and New Zealand ${ }^{57}$ have developed important statutory law.

Property law is also a remarkable illustration in this context. ${ }^{58}$ Created by courts, property rights are always conveyed as a result of an exchange among people. It is both important to determine who owns the right to control a certain resource or a specific good and to discover the ability of the owner to transmit or limit the use of the resource. The problem is common to movable as well as real estate property. In the latter case, given the costs and the use as collateral in modern economics, it is more relevant to identify the owner and to know the legal status of the property in order to protect purchasers. It is easy to understand that, in every legal system, a great part of the rules governing real estate property is intended to promote a reliable way to convey and exchange property. The main goal involves the protection of potential purchasers and their abilities to get loans. As it is well-known, real estate security and stability play a role of the utmost importance in economic growth.

The Torrens system of land registration was developed in the nineteenth century in Australia. ${ }^{59}$ It was later implemented in New Zealand, Western Canada, and other British possessions. ${ }^{60}$ However, in many areas of Britain (mainly Scotland and Ireland), Canada, and the United States, a traditional

developing appropriate procedures for multiparty litigation has been noticed by legal scholars. In this matter, see the discussion in Rachael Mulheron, The Class Action in Common LAW LEGAL SYSTEMS (2004).

53 Australia has no Bill of Rights. Individual rights have been expanded by the case law of the Australian High Court. See generally James Allan, You Don't Always Get What You Pay For: No Bill of Rights for Australia, 24 N.Z. U. L. REV. 179 (2010).

${ }^{54}$ Bill of Rights, 1689, 1 W \& M., c. 2 (Eng.); Human Rights Act, 1998, c. 42 (Eng.); see David Erdos, Ideology, Power Orientation and Policy Drag: Explaining the Elite Politics of Britain's Bill of Rights Debate, 44 GOV'T \& OpPOsITION 20 (2009) (framing the Human Rights Act as part of a Bill of Rights agenda).

${ }^{55}$ U.S. CONST. amends. I-X.

56 Canadian Charter of Rights and Freedoms, Part I of the Constitution Act, 1982, being Schedule B to the Canada Act, 1982 (U.K.).

57 New Zealand Bill of Rights Act 1990; see David Erdos, Aversive Constitutionalism in the Westminster World: The Genesis of the New Zealand Bill of Rights Act (1990), 5 INT'L J. CONST. L. 343 (2007) (demonstrating the aversive model of constitutionalization of rights in established democrasies); David Erdos, Judicial Culture and the Politicolegal Opportunity Structure: Explaining Bill of Rights Legal Impact in New Zealand, 34 LAW \& SoC. INQUIRY 95 (2009) (arguing that New Zealand bill of rights case law has been largely confined to criminal or freedom of speech issues, a culture established from British judicial norms).

58 Robert CoOTER \& ThOMAs Ulen, LAW AND ECONOMics (3d ed. 2011).

59 TheOdore B.F. RuOFF, An Englishman LoOKS AT the TORRENS System 1-2 (1957).

${ }^{60}$ John L. McCormack, Torrens and Recording: Land Title Assurance in the Computer Age, 18 WM. MitChELl L. ReV. 61, 95 (1992). 
system of land recording has persisted. ${ }^{61}$ The main difference between these two title systems is that registration generates a provisional priority for claims, whereas recording does not. ${ }^{62}$ As a consequence, in the case of a valid claim by a third party, the current owner keeps the land under registration (the rightful claimant gets compensated by the public system of registration), whereas under recording the current owner loses the land (but usually receives compensation if an insurance mechanism is in place).

Recording and registration have been shaped by judge-made law, but the Torrens system was not introduced by the courts. ${ }^{63}$ A similar analysis can be developed for adverse possession. The traditional common law approach to adverse possession has been changed by important legislation in the United Kingdom, ${ }^{64}$ where significant differences are now observable. ${ }^{65}$

\section{The Role of Statute Law}

One immediate explanation for observed differences across common law countries could be the asymmetric role of statute law. ${ }^{66}$ Even if statutory law prevails over judge-made law in all common law jurisdictions today, such

61 Id. at 129 n.5.

62 Benito Arruñada, Property Enforcement as Organized Consent, 19 J.L. ECON. \& ORG. 401, 420-21 (2003); Benito Arruñada \& Nuno Garoupa, The Choice of Titling System in Land, 48 J.L. \& ECON. 709, 711 (2005); Benito Arruñada, Property Titling and Conveyancing, in RESEARCH HANDBOOK ON THE ECONOMICS OF PROPERTy LAW 237, 240-44 (Harry Smith \& Ken Ayotte eds., 2010); Garoupa \& Ligüerre, supra note 17, at 312-13 ("The alleged superiority of the registration system is not immune to criticism. Registration helps property transactions, as well as the use of property as collateral, by reducing uncertainty. However, it is a more expensive and demanding system because the cost of purging titles is not negligible. Consequently, it could be that a more expensive system, such as registration, expels an important fraction of property from the public system. On the other hand, recording is a cheaper titling system, and therefore the fraction of property expelled from the public system is presumably lower. Clearly, there is a trade-off between the assurance of quality of titling in land and the expulsion of property from the public system. From a theoretical perspective, it is not clear which titling system is better for the enforcement of property rights.”).

63 RuOFF, supra note 59.

${ }^{64}$ Land Registration Act, 1925, 15 \& 16 Geo. 5, c. 21 (Eng.); Land Registration Act, 2002, c. 9 (Eng.).

65 See Thomas J. Miceli \& C.F. Sirmans, An Economic Theory of Adverse Possession, 15 INT'L REV. L. \& ECON. 161 (1995) (discussing the underlying economic rationale of the adverse possession doctrine); Todd Barnet, The Uniform Registered State Land and Adverse Possession Reform Act, a Proposal for Reform of the United States Real Property Law, 12 BufF. ENVTL. L.J. 1 (2004) (analyzing the Land Registration Acts of 1925 and 2002 and other aspects of the U.K. registration system); Barbara Bogusz, Bringing Land Registration into the Twenty-First Century - The Land Registration Act 2002, 65 MoD. L. Rev. 556 (2002) (analyzing the effects of the Land Registration Act of 2002); Amnon Lehavi, The Property Puzzle, 96 Geo. L.J. 1987 (2008) (analyzing the effects of the Land Registration Act of 2002).

${ }^{66}$ See Priya P. Lele \& Mathias M. Siems, Diversity in Shareholder Protection in Common Law Countries, J. InSTITUTIONAL COMPARISONS, Spring 2007, at 3 (discussing differences in shareholder protection law among common law countries). 
preponderance varies. In that case, the potential inefficiencies could be possibly unrelated to the common law itself; in particular, if we take the view suggested by legal economists that statute law is intrinsically less efficient than judge-made law. ${ }^{67}$ In fact, one of the main arguments for the superiority of judge-made law is that private interests are more likely to capture the legislature than the courts, although we think that such argument is debatable at the theoretical as well as at the empirical level. ${ }^{68}$ From our perspective there is no systematic evidence that rent-seeking is more persistent with the legislature than with the courts, since demand and supply conditions are fundamentally different. ${ }^{69}$ Moreover, courts and legislators have their own goals in terms of enhancing their influence, which complicates the potential effect of private interests in lawmaking. ${ }^{70}$ However, we recognize that using statute law as the main source to explain differences across common law jurisdictions would be self-defeating in the eyes of those who believe in the efficiency hypothesis of the common law.

Our approach in this Article does not mean we reject the view held by other legal scholars that the interaction of judge-made law and statute law might actually improve rather than hurt convergence for efficiency. Most likely an appropriate mix of judicial precedent and statute rule should be the efficient outcome. ${ }^{71}$ Otherwise, given the growth of statute law in all

67 See Andreas Engert \& D. Gordon Smith, Unpacking Adaptability, 2009 BYU L. REV. 1553, 1562 (stating that "increasing the adaptability of the law-and hence making the law less predictable-is not a general policy advice to enhance overall efficiency”).

${ }^{68}$ See Michael A. Crew \& Charlotte Twight, On the Efficiency of Law: A Public Choice Perspective, 66 PuB. Choice 15 (1990) (arguing that common law is less subject to rentseeking than statute law); see also Paul H. Rubin, Common Law and Statute Law, 11 J. LEGAL STUD. 205 (1982) (arguing that both common law and statute law are influenced by private interests to advance their goals). The most devastating criticism is GoRDON TULLOCK, THE Case Against the Common LaW (1997) and Gordon Tullock, Rent-Seeking and the Law, in 5 The Selected Works of Gordon Tullock 184 (Charles K. Rowley ed., 2005). See also Todd J. Zywicki, Spontaneous Order and the Common Law: Gordon Tullock's Critique, 135 Pub. CHOICE 35 (2008) (examining comparative attributes of the common and civil law systems).

${ }^{69}$ William M. Landes \& Richard A. Posner, The Independent Judiciary in an Interest Group Perspective, 18 J.L. \& Econ. 875 (1975); W. Mark Crain \& Robert D. Tollison, Constitutional Change in an Interest-Group Perspective, 8 J. LEgAL STUD. 165 (1979); W. Mark Crain \& Robert D. Tollison, The Executive Branch in the Interest-Group Theory of Government, 8 J. Legal STUD. 555 (1979); Fred S. McChesney, Rent Extraction and Rent Creation in the Economic Theory of Regulation, 16 J. LEGAL STUD. 101 (1987) (discussing several theories of capture in rulemaking); Thomas W. Merrill, Does Public Choice Theory Justify Judicial Activism After All?, 21 Harv. J.L. \& PUB. POL'Y 219 (1997); Howard S. Erlanger \& Thomas W. Merrill, Institutional Choice and Political Faith, 22 LAW \& Soc. INQUIRY 959 (1997).

70 A.C. Pritchard \& Todd J. Zywicki, Finding the Constitution: An Economic Analysis of Tradition's Role in Constitutional Interpretation, 77 N.C. L. REV. 409, 447-48 (1999).

${ }^{71}$ For a technical model, see Giacomo A. M. Ponzetto \& Patricio A. Fernandez, Case Law Versus Statute Law: An Evolutionary Comparison, 37 J. LEgAL STUD. 379 (2008) (predicting 
common law jurisdictions, the obvious conclusion should be that the overall efficiency has been reduced considerably in recent times. ${ }^{72}$ The argument that the efficiency of the common law is not really demand-side induced (i.e., through the incentives provided by litigation) but supply-side induced reinforces this drastic conclusion. According to this version, the historical competition between common law and equity courts was the driving force; once these courts were merged and a monopoly had been achieved, the efficiency forces had lost stimulus. ${ }^{73}$

Still, for the purpose of clarifying our arguments, both in the theoretical discussion as well as in the examples we consider, we have intentionally excluded the role of statute law as far as we can. In other words, we focus primarily on doctrinal and rule diversity fostered by judge-made law.

\section{Choice of Common Law Jurisdictions}

Our discussion focuses on "pure" common law jurisdictions such as the United States (neglecting Louisiana for the purpose of the paper), Canada (excluding Quebec in our analysis), England and Wales, Ireland, Australia or New Zealand. The reason is to make sure the observed relevant differences are not induced by other elements of the legal system that prevail in "mixed" jurisdictions such as Israel or South Africa (by no means do we underplay the potential influence of Quebecois civil law in Canadian common law). ${ }^{74}$

the progressive convergence of common and civil law toward a mixed system); Carmine Guerriero, Democracy, Judicial Attitudes, and Heterogeneity: The Civil Versus Common Law Tradition (Univ. Cambridge, Working Paper No. 917, 2008) (arguing that case law outperforms statute law when political institutions are weak).

${ }^{72}$ See Rubin, supra note 21, at 23 (noting that the common law might have been more efficient in the past when the organization of interests was more costly, but not now). Also, these arguments face a serious challenge in areas such as antitrust law that might be statute law precisely because the traditional principle of fair trade in common law did not protect market competition and courts were excessively deferential to monopolies. THE CAUSES AND CONSEQUENCES OF ANTITRUST (Fred S. McChesney \& William F. Shughart II eds., 1995).

${ }^{73}$ See generally Todd J. Zywicki, The Rise and Fall of Efficiency in the Common Law: A Supply-Side Analysis, 97 Nw. U. L. REV. 1551 (2003) (arguing for supply-side explanations based on competition between several court systems, in particular common law and equity). A more comprehensive discussion is provided by Daniel Klerman, Jurisdictional Competition and the Evolution of the Common Law, 74 U. CHI. L. REV. 1179 (2007), who argues that institutional structures that were able to produce more innovative legal rules tended to prevail in English law. However, he challenges the efficiency of the supply-side competition between these courts. He notes that there was a pro-plaintiff bias that generated certain (hardly efficient) rules given the way judges were paid. Important changes to judicial compensation and salaries corrected the pro-plaintiff bias in the nineteenth century.

${ }^{74}$ See, e.g., Esin Örücü, General Introduction: Mixed Legal Systems at New Frontiers, in Mixed Legal Systems at New Frontiers (Esin Örücü ed., 2010); Vernon Valentine Palmer, Two Rival Theories of Mixed Legal Systems, in Mixed Legal Systems At New Frontiers, supra. 
At the same time, we prefer to frame our discussion in the context of those jurisdictions rather than the American states (as well as the Canadian provinces or the Australian states) because it seems more appropriate when having in mind the current mathematical models of the evolution of the common law. Clearly there are important variations in common law within the American states. At the same time, given that they belong to a political union and are subject to identical federal law as well as the jurisdiction of the U.S. Supreme Court, there is an inevitable contamination effect that shapes convergence. It seems to us that jurisdictions that are not part of the same political and institutional unit provide for a better testing of our predictions.

The following Part discusses the origins of the efficiency hypothesis of the common law and the relevant variables to explain differences across common law jurisdictions fostered by case law. In Part III, we discuss examples of legal doctrines and rules that seem to be addressed differently across the common law world. Part IV concludes the paper.

\section{THE EFFICIENCY OF THE COMMON LAW HYPOTHESIS}

If the common law is to be efficient, certainly there must be strong reasons to support such an assertion. One immediate explanation for the Posnerian hypothesis is that judges have a preference for efficiency. ${ }^{75}$ If judges pursue efficiency as the goal of law, it is no surprise that the common law is efficient. However, this does not seem to be a persuasive argument. Why would judges care about efficiency rather than equality or other possible goals? Moreover, from an empirical perspective, we now have an extensive literature showing that ideology and other significant nonefficiency-oriented variables play a major role in explaining judicial behavior. $^{76}$ From a comparative perspective, the argument is also unpersuasive since there seems to be no strong reason for why American judges would care more or less about efficiency than Canadian or Australian judges.

A second possible explanation is that efficiency is promoted by the prevalence of precedent (more efficient rules are more likely to survive through a mechanism of precedent). ${ }^{77}$ Another explanation relies on the incentives to bring cases and the role of court litigation (since inefficient rules are not welfare-maximizing). ${ }^{78}$ Nevertheless, these two explanations

\footnotetext{
75 Richard A. Posner, Utilitarianism, Economics, and Legal Theory, 8 J. LEGAL STUD. 103 (1979).

${ }^{76}$ See, e.g., Barry Friedman, The Politics of Judicial Review, 84 TEx. L. REv. 257 (2005) (arguing political ideology of members of the judiciary help explain judicial behavior).

77 Paul H. Rubin, Why Is the Common Law Efficient, 6 J. LEGAL STUd. 51, 53 (1977).

${ }^{78}$ George L. Priest, The Common Law Process and the Selection of Efficient Rules, $6 \mathrm{~J}$. LEGAL STUD. 65, 65 (1977).
} 
require a particular mix of case litigation in order to derive an efficient outcome. In particular, variations concerning the prevalence of precedent (that traditionally was stronger in England than in America) and the mix of case litigation could explain differences across the common law world. However, it is unclear if such variations or differences indicate that the common law only achieves efficiency under some specific conditions.

In fact, the search for a more convincing setup for the efficiency of the common law hypothesis has sparked important academic work. This literature essentially looks at how litigation improves the law, or some specific legal doctrine, taking into consideration that only a self-selected number of cases is actually litigated. ${ }^{79}$

The efficiency of the common law must be unequivocally related to the observation that litigation follows private interests. ${ }^{80}$ Presumably it is true that bad rules are challenged more often than good rules, so naturally court intervention could improve the overall quality of the law. However, this line of reasoning is not without problematic shortcomings. It could be that the subset of cases that are actually litigated are not representative enough to trigger the necessary improvements, hence biasing evolution of legal rules against efficiency. ${ }^{81}$ Furthermore, the emergence of efficiency in common law necessarily depends on a number of factors in the evolutionary mechanism, namely initial conditions, path dependence, and random shocks. ${ }^{82}$

79 See John C. Goodman, An Economic Theory of the Evolution of Common Law, 7 J. LEGAL STUD. 393, 394 (1978) (arguing that the probability that a particular litigant will win a favorable decision); Robert Cooter \& Lewis Kornhauser, Can Litigation Improve the Law without the Help of Judges?, 9 J. LEGAL STUD. 139, 156 (1980) (arguing "the law can improve by an unguided evolutionary process”); R. Peter Terrebonne, A Strictly Evolutionary Model of Common Law, 10 J. Legal Stud. 397 (1981); Paul H. Rubin, Business Firms AND the Common LAW (1983); Georg von Wagenheim, The Evolution of Judge-Made Law, 13 INT'L REV. L. \& Econ. 381 (1993); Vincy Fon \& Francesco Parisi, Litigation and the Evolution of Legal Remedies: A Dynamic Model, 116 Pub. CHOICE 419 (2003); Vincy Fon et al., Litigation, Judicial Path-Dependence, and Legal Change, 20 EuR. J.L. \& ECON. 43 (2005); Vincy Fon \& Francesco Parisi, Judicial Precedents in Civil Law Systems: A Dynamic Analysis, 26 Int’L Rev. L. \& Econ. 519 (2006); Francesco Parisi \& Vincy Fon, The ECONOMics of LAWMAKING (2009); MAXWELl L. STEARNs \& TODD J. ZyWicki, PubliC Choice Concepts AND ApPLiCATIONS In LAw 464 (2009); Niblett et al., supra note 4, at 325 (showing empirically that rules fail to converge with significant inconsistencies across states); Anthony Niblett, Do Judges Cherry Pick Precedents to Justify Extra-Legal Decisions?: A Statistical Examination, 70 MD. L. REV. 234 (2010). A critical view of this literature is provided by FREDERICK SCHAUER, THINKING LIKE A LAWYER 103-23 (2009).

${ }^{80}$ William M. Landes \& Richard A. Posner, Adjudication As a Private Good, 8 J. LEGAL STUD. 235 (1979) (making the point that judicial opinions are a public good that arbitration fails to provide).

81 Gillian K. Hadfield, Bias in the Evolution of Legal Rules, 80 GEO. L.J. 583, 612-14 (1992).

${ }^{82}$ Mark J. Roe, Chaos and Evolution in Law and Economics, 109 HARV. L. REV. 641, 641 
More recent work has provided a more comprehensive analytical framework to show under which precise mathematical conditions the evolution of the common law tends toward efficiency. ${ }^{83}$ For example, even if judges are ultimately efficiency-seeking, precedent and overruling must be balanced in an appropriate way. A judicial bias might distort the law in the short run but at the same time provide the mechanism to improve the law in the long run, depending on critical elements of the evolution of the common law. ${ }^{84}$ The possibility of selective litigation driven by private interests (likely to be misaligned with social interests) just makes the whole process more complex; convergence to efficiency is still possible as long as the biases are not overwhelming to the point of hurting the likelihood that inefficient laws will be more often litigated. Naturally strong precedent could be socially valuable if judges are significantly biased. ${ }^{85}$

If the Posnerian hypothesis is true, at least in the long run, rules that do not promote efficient results should be repealed in any common law jurisdiction. $^{86}$ Therefore, the central question is why common law jurisdictions have different doctrines in property, contracts, and torts. When common law jurisdictions have a different doctrine in a particular relevant area of the law there could be two possible interpretations. The first interpretation is that the evolution of the common law to efficiency generates multiple equilibria. Therefore, each common law jurisdiction is potentially efficient and there are multiple efficient doctrines depending on local determinants. The second interpretation is that there is one and only one

(1996). For an explanation of path dependence theory, see Oona A. Hathaway, Path Dependence in the Law: The Course and Pattern of Legal Change in a Common Law System, 86 IowA L. REv. 601, 606 (2001) (outlining what she considers to be three strands of path dependency).

${ }^{83}$ See, e.g., Nicola Gennaioli \& Andrei Shleifer, The Evolution of Common Law, 115 J. POL. ECON. 43, 46 n.4 (2007) (discussing following precedent, distinguishing and overruling as leading or not leading to efficiency).

${ }^{84}$ See id.; Nicola Gennaioli \& Andrei Shleifer, Overruling and the Instability of Law, 35 J. COMP. ECON. 309, 323 (2007) (noting that although inefficient laws are more easily litigated and replaced, which improves efficiency over time, this effect can still reduce the long run volatility of the law because it cannot ensure convergence to efficiency); Anthony Niblett, Case-By-Case Adjudication and the Path of the Car 184 (Mar. 2011) (unpublished manuscript) (available at http://works.bepress.com/Anthony_niblett/1/) (arguing that polarization concerning precedent depends on judicial preferences, cases that get litigated, and cost of adhering to precedent).

85 See Thomas J. Miceli, Legal Change: Selective Litigation, Judicial Bias, and Precedent, 38 J. LEGAL STUD. 157, 165 (2009) (stating that "binding precedent plays no role in enhancing the efficiency of the law, but it can play a potentially important role in limiting the ability of biased judges to drive the law in an inefficient direction”); Luca Anderlini et al., Why Stare Decisis? (Working Paper, 2010) (available at http://ssrn.com/abstract=1616708) (arguing that stare decisis guarantees ex ante efficient decisions).

${ }^{86}$ See Gennaioli \& Shleifer, supra note 83, at 45 (referring to the Priest and Rubin theories "that disputes involving inefficient legal rules are more likely to be taken to court" and thus replaced "by better ones over time"). 
efficient equilibrium, and many common law jurisdictions simply fail to achieve it. We use the analytical models developed in the law and economics literature to identify the two possibilities and understand the implications. ${ }^{87}$ Quite the contrary, these possibilities are not mutually exclusive. Hence, we conclude this Part by addressing the more realistic model which allows for the coexistence of both interpretations.

\section{A. Multiple Efficient Equilibria}

When the fundamentals of the model vary across jurisdictions, we could have multiple efficient equilibria. Each jurisdiction converges to an efficient doctrine and rule in the long run, but they are not the same because there are local conditions and aspects that vary significantly. ${ }^{88}$

The process of convergence to an efficient and stable equilibrium is based on selective litigation. The selective litigation could be different across the common law world in response to local conditions and asymmetric shocks caused by local historical events. The circumstances under which an original rule or doctrine in common law is applied in different jurisdictions varies dramatically, since different sets of cases are litigated. As a consequence, the conditional probability that a given inefficient rule is challenged is not the same. ${ }^{89}$ Therefore, the evolution of the common law follows different paths. Of necessity, the pattern of path dependence will be consistently diverse leading to distinctive, but equally efficient, equilibria. ${ }^{90}$

Legal historians seem to perceive this effect in explaining the development of the English common law and the early American common law. Colonial law responded mainly to local problems and conditions faced by the European settlers, which were radically distinct from the realities of the English (and possibly the Irish) society. ${ }^{91}$ However, relying on these differences that resulted in dissimilar selective litigation to explain significant variations across the American colonies, Canada, Australia and New Zealand seems less persuasive.

\footnotetext{
${ }^{87}$ In particular, we focus on Gennaioli \& Shleifer, supra note 83; Miceli, supra note 85; Ponzetto \& Fernandez, supra note 71; and Wagenheim, supra note 79.

${ }^{88}$ Gennaioli \& Shleifer, supra note 84, at 323-47.

89 See Miceli, supra note 85 (arguing that the rate of creation of inefficient rules depend upon the strength of governing precedent); Wagenheim, supra note 79.

90 See Roe, supra note 82, at 647-48 n.11 (stating that in applying a path dependency model when there are multiple results, one outcome need not be better than the other because each could have been good enough, where the author uses a weak-path dependency to indicate multiple equilibria); Hathaway, supra note 82, at 634-35 (using the rule against perpetuities as an example of how the rule developed because of history and that its existence, while explainable, was not necessarily a unique equilibrium, indicating that given other circumstances an equally efficient alternative rule may have been possible).

${ }^{91}$ FRIEDMAN, supra note 29.
} 
If there are multiple efficient equilibria due to distinctive selective litigation, the implications for the efficiency hypothesis of the common law are twofold. First, the one-size-fits-all approach taken by the legal origins literature is undermined. There is no single or unique common law as assumed by that literature, but a multiplicity of common law systems. The focus on a particular doctrine or rule is not very informative concerning the efficiency of legal arrangements, since the appropriate response varies across the common law jurisdictions. Second, under the efficiency hypothesis of the common law, when a particular jurisdiction adopts the common law approach as suggested by the legal origins literature, the "efficient" outcome is difficult to predict since particular local determinants might generate yet another completely new path. ${ }^{92}$

Multiple efficient equilibria signal that the world is more complex than the approach taken by the legal origins literature. A mistaken focus on legal outcomes hides the interaction of different local determinants with dissimilar path dependencies. Under the current analytical models, the assessment of legal outcomes concerning efficiency cannot be disentangled from the varying selective litigation in each jurisdiction; certainly that has not been the approach taken by the legal origins literature.

\section{B. Single Efficient Equilibrium}

Another possibility is that there is a single efficient equilibrium. Immediately we recognize that some common law jurisdictions seem to develop the efficient doctrine or rule, whereas others do not. There are several possible explanations for why some common law jurisdictions fail to achieve efficiency.

One possible reason is that the distribution of relevant attributes of judicial preferences is not the same. ${ }^{93}$ For example, the proportion of proplaintiff and pro-defendant judges varies, with the consequence that the number of pro-efficient rule judges is different, and in some cases insufficient to force convergence to efficiency. ${ }^{94}$ Alternatively, the biases

92 See generally Hathaway, supra note 82, at 634-35 (in explaining how the rule of perpetuities exemplifies increasing path dependence, stating that despite being able to ascertain how the rule of perpetuities came into existence, the final outcome selecting that approach would have been difficult to predict in advance and that given another set of historical circumstances the rules governing inheritance could have developed differently).

${ }^{93}$ See Gennaioli \& Shleifer, supra note 84, at 316 (claiming that the optimal (efficient) legal rule should be unbiased and that unless all judges are unbiased (which they are not), judge made law cannot achieve this outcome).

${ }_{94}^{4}$ See Miceli, supra note 85, at 163 (assuming that precedent continues to be nonbinding, judges will decide cases that come before theme based solely on these preferences, meaning pro-plaintiff judges will uphold pro-plaintiff cases and overrule pro-defendant cases and vice versa). 
favoring certain types of rules vary across the population of judges. In particular, more polarized judiciaries are less likely to achieve efficient doctrines and rules. ${ }^{95}$ Efficiency requires a more unbiased judiciary and therefore more judicial polarization leads to significant social welfare losses. $^{96}$ At the same time, a varying degree of influence of special interest groups in judicial politics could contribute toward shaping behavior in different ways that preclude some particular institutional arrangements from converging to efficiency. ${ }^{97}$ Moreover, the concern about the future evolution of the law measured by a specific discount factor (for example, how forward looking judges are) plays an important role in explaining efficiency. A judiciary too focused on the short run and less so on the long run is less likely to generate an efficient legal outcome. ${ }^{98}$

There are good reasons to think that the distribution of relevant judicial attributes varies across common law jurisdictions, with the U.S. judiciary probably being distinct from other common law judiciary. ${ }^{99}$ From the perspective of the current available models, these differences could be a byproduct of specific appointment mechanisms (that can polarize the judiciary or empower the influence of special interest groups), judicial tenure (including mandatory retirement), promotion and retention policies, or recruitment strategies (a wider or narrower pool of potential candidates to the judiciary that breeds different degrees of heterogeneity in the bench). The most interesting implication of these considerations is that most probably the U.S. is the jurisdiction with the least likely judiciary (within the common law jurisdictions) to promote efficient legal outcomes according to the mathematical models.

Another reason for why some common law jurisdictions fail to converge to efficiency is the role of precedent. If the cost of changing precedent is too low, judicial biases prevail and the legal outcome in the long run is unlikely to be efficient. ${ }^{100}$ To put it differently, the judicial gains from getting closer to an efficient outcome are insufficient when it is easy to change

${ }^{95}$ Gennaioli \& Shleifer, supra note 84, at 311, 315.

${ }^{96}$ Id. at 313.

97 See Ponzetto \& Fernandez, supra note 71, at 398 (identifying that judges are subject to additional pressures like those from interest groups and as a result their decisions are more variable than legislation because they depend not only society-wide general and special interests but also the interests of the parties appearing before them in court).

${ }^{98} \mathrm{Id}$. at 382 (claiming that in the long run the dynamic properties of judge-made law make it an average more efficient).

99 See Richard A. Posner, LaW AND Legal Theory in the UK AND USA (1996) (comparing and contrasting the divergent evolution of the common law in the U.K. and U.S.).

100 See Miceli, supra note 85, at 165 ("[T] diverge from it) more quickly as ...the cost of abandoning precedent[] becomes small....”); Gennaioli \& Shleifer, supra note 83, at 56 (arguing that if the initial legal precedent is precise, the subsequent legal rules become more, and not less, precise). 
precedent. $^{101}$ Consequently the value of precedent plays an important role. Frequent defections from an established precedent undermine the process of converging to efficiency. In the context of the common law jurisdictions, there are important differences on how precedent is respected. U.S. judges seem to be more willing to change precedent than the English judiciary as a general observation (with particular reference to horizontal precedent). ${ }^{102}$ Again, if that is so, it seems likely that the American common law is less likely to achieve efficiency than the English common law.

There are important implications from a model with a single efficient equilibrium. The most immediate is that if doctrines and rules vary across the common law jurisdictions, only one is efficient and the remaining failed to achieve it. Given that the initial condition was presumably the same (English law) we can conclude that some judicial intervention helps efficiency but, under different conditions, judicial intervention is detrimental.

Another inference from this model is that the common law is efficient only under certain conditions. Not all common law jurisdictions satisfy those conditions, both in terms of judicial attributes and cost of changing precedent. A comparison across common law jurisdictions demands a focus on the local judiciary and the stickiness of precedent.

The consequences for the legal origins literature are quite obvious. A single efficient equilibrium supports the idea of a one-size-fits-all approach. However, the details are the conundrum in this context as what we have is the potential efficiency of a specific common law system. At the same time, there are clear prescriptions to improve the performance of each common law institutional arrangement, in terms of reforming the judiciary and the preponderance of precedent.

\section{Putting Both Models Together}

Combining the two possible models we have considered so far, we derive a more complex and realistic overview of the efficiency hypothesis of the common law. First, there is not a single efficient rule or doctrine, but a multiplicity of possible equilibria depending on selective litigation. Second, for each specific set of selective litigation, there is no guarantee that there will be convergence to efficiency, depending on judicial attributes and the preponderance of precedent.

101 See Wagenheim, supra note 79.

102 Posner, supra note 99; see also E.M. Wise, The Doctrine of Stare Decisis, 21 WAYNE L. REV. 1043, 1045-46 (1975) (finding that the American judiciary congratulated itself from moving away from the strict English doctrine of precedent); Thomas R. Lee, Stare Decisis in Historical Perspective: From the Founding Era to the Rehnquist Court, 52 VAND. L. ReV. 647, 664 n.84 (1999) (explaining that the U.S. Supreme Court would have the power to overrule itself on the horizontal plane). 
The most important consequence is that the identification of the efficiency of the common law is much more intricate and multifaceted than anticipated by the literature. A mere comparison of how a specific predicament is addressed in each jurisdiction, as inspired by the legal origins literature, is not only insufficient but also likely to produce gross mistakes. The observation that each jurisdiction provides a different legal outcome says very little about efficiency due to the existence of multiple efficient solutions and because the variables that determine efficient outcomes vary. A proper analysis requires a clear understanding of local determinants, including judicial preferences, before we can jump to the conclusion that the common law is undoubtedly efficient.

The next section introduces relevant examples to illustrate the difficulties of the exercise. They show that once we depart from a general and undefined efficiency hypothesis of the common law into specific doctrines and rules, the analysis is complex, dense, and less clear than the legal origins literature portrays. They also illustrate situations where multiple equilibria are more likely and where a single efficient equilibrium is probable.

\section{DISCUSSION OF EXAMPLES}

We look at illustrative examples starting with tort law, generally speaking, then the particularities of defamation and professional responsibility, followed by cost rules in civil litigation (we argue this is a good candidate for multiple equilibria), and conclude with civil juries (the diversity in the use of civil juries seems to provide an excellent example of an inefficient equilibrium). These examples are not exhaustive or suggested to be representative. Our choice of tort and procedure is merely practical. The differences across common law jurisdictions on tort law and procedure are widely documented. At the same time, they easily relate to theoretical and empirical literature in law and economics that is helpful in assessing the plausibility of multiple efficient equilibria in the context of our discussion.

\section{A. Tort Law}

Tort law is one of the fields of law in which differences among common law jurisdictions are more acute and significant. Even though they have an identical origin in the old English common law, general theories on recovery and judgments have evolved in a different way in each and every jurisdiction. Clearly, all of them have in common the same foundational legal authorities. For abnormally dangerous things or activities, all quote the doctrine stated in Rylands v. Fletcher, ${ }^{103}$ an English decision rendered by the

103 Rylands v. Fletcher, [1868] 3 L.R.E. \& I. App. 330 (H.L.). 
House of Lords in 1868. The case established law according to which a person who carries out an activity that substantially increases the probability of causing harm to others assumes a stricter standard of liability. ${ }^{104}$ In the same vein, common law jurisdictions share the doctrine of Davies $v$. Mann. ${ }^{105}$ This is another important English case that established the last clear chance doctrine, the most commonly accepted modification of the contributory negligence rule. ${ }^{106}$ Likewise, it is needless to point out the great influence of the English admiralty law in the general evolution of the common law of torts.

Although the old common law has influenced all jurisdictions, it has also grandfathered different and variable trends, especially regarding the compensation of personal injuries. ${ }^{107}$ While some jurisdictions still apply the general doctrines in a very similar way to their original conception, others have established new doctrines based on punitive damages or even damages calculated by caps. ${ }^{108}$

More specifically, while Canada, Ireland, Australia, and-obviously-the United Kingdom have remained quite similar to the principles which inspired the function of tort law institutions in early English law; other jurisdictions, in particular New Zealand and the U.S., have experienced a deep transformation in the last decades. ${ }^{109}$

In the vast sectors of the U.S. law culture, tort law has come under fire in the last couple of years. ${ }^{110}$ The biases of the civil juries in tort cases, and the

\footnotetext{
104 For a general explanation on Rylands $v$. Fletcher, and other English cases related with the origins of the strict liability doctrine, see W. Page Keeton et Al., Prosser and Keeton on THE LAW OF TORTS 545-48 (5th ed. 1984).

105 Davies v. Mann, (1842) 152 Eng. Rep. 588 (Ex.).

106 See KeEtON ET AL., supra note 104, at 462-64 (laying out the affirmative defense of the last clear chance doctrine).

107 Compensation for Damage: An International Perspective (Sheila A.M. McLean ed., 1993) (giving general background on the law of damages); TORT AND INSURANCE LAW Vol. 4: Compensation fOr Personal InJury in a Comparative Perspective (Bernard A. Koch \& Helmut Koziol eds., 2003) [hereinafter TORT AND InsURANCE LAW] (giving general background on the law of damages); see also Jeffrey O'Connell \& David Partlett, An America's Cup for Tort Reform? Australia and America Compared, 21 U. Mich. J.L. ReFORM 443, 445-54 (1988) (detailing the different avenues of tort reform).

${ }^{108}$ O’Connell \& Partlett, supra note 107.

109 For a general explanation of the evolution of the system, see G. EDWARD WhITE, TorT LAW IN AmERica: AN InTELleCtual History (2003). For a survey of New Zealand tort law, see Rosemary Tobin \& Elsabe Schoeman, The New Zealand Accident Compensation Scheme: The Statutory Bar and the Conflict of Laws, 53 AM. J. CoMP. L. 493 (2005) (detailing the New Zealand accident compensation scheme).

110 See Frank B. Cross, Tort Law and the American Economy, 96 MinN. L. REV. 28, 47-50 (2011) (noting that the studies of tort law reform have been flawed). For a survey of judicial opinions on tort law and reform, see Larry Lyon et al., Straight from the Horse's Mouth: Judicial Observations of Jury Behavior and the Need for Tort Reform, 59 BAYLOR L. REV. 419 (2007).
} 
alleged excessive amounts established in the context of punitive damages, have promoted a general sense that a reform of the tort system is needed. ${ }^{11}$ Some U.S. jurisdictions have been named as "judicial hellholes" by the American Tort Reform Association, ${ }^{112}$ a movement that reports on spurious litigation in tort and promotes legal change in order to contain the increase of damages.

In New Zealand, almost all personal injury damages actions are now barred from reaching the courts. Since 1974, damages are decided by a government agency, the Accident Compensation Corporation, which promotes no-fault benefits for victims of accidents. ${ }^{113}$ The tasks of the agency have been expanded to include more areas of the law in the last decades. Its origins are linked to the damages due from labor accidents. Like in the vast majority of jurisdictions (both common law and civil law), damages are calculated on an objective basis previous to the claim being filed. For example, New Zealand is establishing objective criteria for medical malpractice claims. ${ }^{114}$ Damages are calculated by caps that standardize compensations and bar the discussion on damages and compensation in the courts of law. ${ }^{115}$

New Zealand has embraced a pure compensation system that completely replaced the common law remedies for tort, an approach pursued by other jurisdictions for workers' compensation only. ${ }^{116}$ In fact, the Woodhouse Report, so called in honor of the president of the commission that launched the reform, began its discussion focused on the alternative ways to improve

${ }^{111}$ For example, see Liebeck v. McDonald's Restaurants, No. CV-93-02419, 1995 WL 360309 (N.M. Dist. Aug. 18, 1994), the so-called “McDonald's Coffee Case,” where the jury awarded \$2.86 million to a woman who burned herself with a cup of coffee she purchased at a McDonald's restaurant. See Thomas S. Ulen, The View from Abroad: Tort Law and Liability Insurance in the United States, in TORT LAW AND LIABILITY INSURANCE 207-38 (Gerhard Wagner ed., 2005).

112 AM. TORT REFORM Ass’n, JUdicial Hellholes 2011/2012 (2011), available at http://www.j udicialhellholes.org/wp-content/uploads/2011/12/Judicial-Hellholes-2011.pdf. The American Tort Reform Association was founded in 1986. Since then it has focused on promoting the controleven statutorily — of the damages award to plaintiffs in civil tort cases. About ATRA, ATRA.orG, http://www.atra.org/about/ (last visited Feb. 13, 2012)

${ }^{113}$ A complete study on the initial consequences of the reform can be found in GEOFFREY

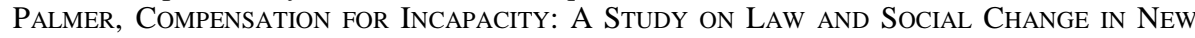
ZEALAND AND AUSTRALIA (1979).

114 See generally Peter H. Schuck, Tort Reform, Kiwi-Style, 27 YAlE L. \& POL'y Rev. 187 (2008) (describing New Zealand's tort reform).

115 Some jurisdictions, including civil law countries, have followed the New Zealand example. Spain, for instance, has since 1995 implemented a statutory cap system for calculating damages for personal injuries caused by traffic accidents. Jesús Pintos Ager, Damage Schedules \& Tort Litigation in Spain 3-4 (InDret, Working Paper No. 131, 2003) (available at http://www.indret. com/pdf/131_en.pdf).

116 PALMER, supra note 113; Schuck, supra note 114, at 188; Tobin \& Schoeman, supra note 109 , at 493. 
workers' and road accident victim's compensation schemes. At that point, the members of the commission realized that spreading the system for all personal injuries caused by accidents and criminal offenses would reduce administrative costs. ${ }^{117}$ The most profound reform of the common law of torts began as a political decision, but did not find antagonism among the judiciary, and it has been fairly consensual in New Zealand. ${ }^{118}$

The abovementioned examples show how deep the differences are in tort law within the common law jurisdictions. ${ }^{119}$ As we have mentioned before, it is debatable that tort law evolves to efficiency. ${ }^{120}$ The different trends followed in the common law jurisdictions make it even harder to talk about a common law of torts (since they are remarkably different by now) and which of them is more appropriate from an economic perspective. The creative developments in New Zealand make this jurisdiction a clear outlier at the moment. Yet, from an economic perspective, there are significant advantages (legal certainty, reduction of litigation costs) and important disadvantages (inappropriate compensation, ossification of the law). It is unclear if the New Zealand reform is efficient inasmuch as the common law principles of tort law could be inefficient. In the following two subsections, we look at further examples in detail.

\section{B. Defamation Law}

Defamation is a tort concerned with the publication of false defamatory statements about another person that tend to injure a person's reputation by degrading them in the opinion of their neighbors or to make them ridiculous. ${ }^{121}$ Defamation can be divided into libel, in which publication is in a permanent form, and slander, which is oral publication. ${ }^{122}$ To find an action for publication, the offending matter must be published with a third party. $^{123}$

\footnotetext{
117 Australia tried to enact a similar system. The proposal was, anyway, more comprehensive than the New Zealand system, since Australians aimed to cover the whole population from any personal injury. The proposal never reached the necessary parliamentary majority. For more references on the New Zealand reform and the Australian proposals, see JoHN G. FLEMING, THE LAW OF TORTS 374-78 (8th ed. 1992).

${ }^{118}$ Id.

119 Compensation for Damage: An International Perspective, supra note 107; Tort AND INSURANCE LAW, supra note 107.

120 See Barzel, supra note 47, at 255 (noting that tort law, as a means to delineate rights, tends towards inefficiency but never maintains a constant level of efficiency).

${ }^{121}$ Henry Coleman FolKard, The LaW OF Slander AND Libel 1 (7th ed. 1908).

${ }^{122}$ Id.

${ }^{123}$ Id.
} 
The common law provides for the establishment of a defamation claim in tort and the applicable defenses. ${ }^{124}$ However, judge-made law has significantly changed defamation law in common law jurisdictions. In the United States, libel law came under the influence of federal constitutional law after 1964. In that year, in the case of New York Times v. Sullivan, ${ }^{125}$ the United States Supreme Court ruled that state laws making newspapers strictly liable for false defamatory statements were generally inconsistent with First Amendment rights of freedom of press. ${ }^{126}$ The reasoning was as follows: If public officials are allowed to recover damages for any false and defamatory statement, regardless of the level of care taken, then newspapers will be discouraged, or chilled, from printing stories on matters of public interest. To moderate this chilling effect, the Supreme Court imposed a standard of proof in libel cases involving public official plaintiffs which was much higher than that used in most state courts at the time. ${ }^{127}$

The United Kingdom followed a different approach. The Defamation Act 1952 restated and clarified the common law principles of defamation. ${ }^{128} \mathrm{~A}$ strict liability rule operates and damages are usually compensatory. In the particular case of libel, no damage to the plaintiff has to be proved. In slander, special damage must be proved except where the statement is an imputation of a criminal offense. ${ }^{129}$ With the exception of the special damage, the Defamation Act of 1952 was repealed and replaced by the Defamation Act 1996 and the relevant parts of the Electronic Commerce Regulations 2002. ${ }^{130}$ The new law was partially developed under the influence of previous controversial case law and intended to limit claims of a tort of defamation. ${ }^{131}$

Other common law jurisdictions have restated the common law principles of the tort of defamation in their legislation, such as the New Zealand Defamation Act 1992, the Irish Defamation Act 1961 and Defamation Act 2009, or the Australian model Defamation Act 2006. ${ }^{132}$ These statutes were

\footnotetext{
124 Restatement (Second) of Torts: Witnesses in Judicial ProceEdings § 558 (2011).

125376 U.S. 254 (1964).

${ }^{126} I d$. at 279.

127 Id. at 283.

128 Defamation Act, 1952, 15 \& 16 Geo. 6 \& 1 Eliz 2, c. 66, § 6 (Eng.), available at http:// www.legislation.gov.uk/ukpga/Geo6and1Eliz2/15-16/66.

${ }^{129}$ Milner Frankum et al., United Kingdom, in 2 Media, Advertising, \& EnTERTAinment Law Throughout the World ch. 36 (2010) [hereinafter 2 Media, Advertising, \& ENTERTAINMENT LAW].

${ }^{130}$ Id.

131 Defamation Act, 1996, c. 31 (Eng.), available at http://www.legislation.gov.uk/ukpga/19 96/31/data.pdf; Electronic Commerce Regulations, 2002, S.I. 2002/2555 (U.K.), available at http://www.legislation.gov.uk/uksi/2002/2013/pdfs/uksi_20022013_en.pdf.

${ }_{132}$ Defamation Act 1992 (N.Z.), available at http://www.legislation.govt.nz/act/public/1992/ 0105/latest/DLM280687.html; Defamation Act 2009 (Act No. 31/2009) (Ir.), available at http://
} 
deeply influenced by controversial case law such as Oceanic Sun Line Special Shipping Co. v. Fay or Gutnick v. Down Jones \& Co. in Australia. ${ }^{133}$ In Canada, defamation law is regulated by provincial statutes that have been shaped by legal doctrines developed by the Supreme Court of Canada in salient cases such as Hill v. Church of Scientology. ${ }^{134}$

The significant difference between the United States and the remaining common law jurisdictions is the more generous treatment of defendants in the United States. ${ }^{135}$ Libel law deals with a clash of two important values: freedom of speech and freedom from defamation. The proper balance between these goals has been debated in economics. It is unclear if the American model is closer to efficiency than the traditional common law approach. ${ }^{136}$ Significant differences between the political system, the media industry, or the prevalence of corruption could suggest that the different approaches can be equally efficient depending on local needs.

\section{Professional Responsibility}

Under the traditional principles of the common law, lawyers acting as advocates have professional immunity and could not be sued for professional responsibility. The immunity for misconduct tort litigation was established in the eighteenth century. Although the scope and justification for the immunity have evolved in case law due to public policy considerations, it

www.irishstatutebook.ie/pdf/2009/en.act.2009.0031.pdf; Defamation Act 2006 (NT) s. 25

(Austl.), available at http://www.austlii.edu.au/au/legis/nt/num_act/da20068o2006145/.

133 Oceanic Sun Line Special Shipping Co. v Fay [1988] 165 CLR 197 (Austl.); Down Jones \& Co. v Gutnick [2002] HCA 56 (Austl.).

${ }_{134}$ Hill v. Church of Scientology of Toronto, [1995] 2 S.C.R. 1130 (Can.).

135 Frankum et al., supra note 129; William L. Northcote \& Christopher M. Schiffmann, Canada, in 1 Media, Advertising, \& Entertainment Law Throughout THE World ch. 6 (2010) [hereinafter 1 Media, Advertising, \& Entertainment Law]; Paul Kirton, Australia, in 1 Media, Advertising, \& Entertainment Law, supra, ch. 6; Andrew Fawcett et al., New Zealand, in 2 MEdia, AdVERTISInG, \& EnTERTAinment LAW, supra note 129, ch. 27 (2010); Jonathan Kelly et al., Ireland, in 2 MEdiA, Advertising, \& EnTERTAinMENT LAw, supra note 129 , ch. 17.

${ }^{136}$ See Nuno Garoupa, The Economics of Political Dishonesty and Defamation, 19 INT'L REV. L. \& ECON. 167 (1999) (arguing that tabloids are better informed than society and can provide an auditing role in preventing political corruption so long as they are deterred from defamation); Nuno Garoupa, Dishonesty and Libel Law: The Economics of the "Chilling" Effect, 155 J. Institutional \& THEORETICAL ECON. 284 (1999) (arguing that the plaintiff winning a defamation suit is not a problem if the media can distinguish between honesty and dishonesty); Oren Bar-Gill \& Assaf Hamdani, Optimal Liability for Libel 6 (2003) (demonstrating an alternative model of libel); Manoj Dalvi \& James F. Refalo, An Economic Analysis of Libel Law, 34 E. ECON. J. 74 (2008) (describing another model of liberal law); Ido Baum et al., Reporter's Privilege and Incentives to Leak, 5 REV. L. \& Econ. 701 (2009) (demonstrating that reporters have demonstrable incentives to report leaks, as defamation lawsuits rarely succeed). 
was largely confirmed by the House of Lords in Rondel v. Worsley ${ }^{137}$ and in Saif Ali v. Sydney Smith Mitchell \& Co. ${ }^{138}$ However, more recently, in Arthur J.S. Hall \& Co. v. Simons, the House of Lords has significantly eroded the immunity to the point of effective abolishment by reinforcing the professional duty to the court. ${ }^{139}$ Unlike the House of Lords, the Australian High Court has confirmed the professional immunity for lawyers, as seen in the important case of D'Orta-Ekenaike $v$ Victoria Legal Aid. ${ }^{140}$ The professional immunity was never recognized in Canada or in the United States. The main reasoning seems to be that there was no formal distinction between barrister and solicitor in these jurisdictions.

Although there are important differences in the structure of the legal profession in common law jurisdictions, they do not seem to be a persuasive argument to justify the different approaches from an efficiency perspective. It seems unlikely, from an economic perspective, that a no liability rule can be efficient. Therefore, not only does the traditional principle of immunity in common law seem unlikely to be efficient, but this also presents a case of inefficient persistence.

\section{Cost Rules in Civil Litigation}

The allocation of costs is critically important for civil litigation. In the United Kingdom, the so-called English rule largely prevails. ${ }^{141}$ The general rule is that the unsuccessful party will be ordered to pay the costs of the successful party. However, the award of costs at the conclusion of a case is at the discretion of the court. The discretion extends to whether the costs are payable by one party to another, the amount of those costs, and when they are to be paid. In deciding what order they need to make about costs, the court must give regard to all the circumstances including the conduct of the parties. $^{142}$

In Canada, a rule of shifting of costs in litigation by which the loser in a civil lawsuit must compensate the winner for a portion of the latter's legal costs is also applied. ${ }^{143}$ Generally speaking, costs do not amount to full compensation, and the proportion of the winner's legal bill covered by an

\footnotetext{
137 [1960] 1 A.C. 191 (H.L.).

138 [1980] A.C. 198 (H.L.).

139 Arthur J.S. Hall \& Co. v Simons, [2002] 1 A.C. (H.L.) 615.

140 D’Orta-Ekenaike v Victoria Legal Aid, [2005] 223 HCA 12 (Austl.).

141 See also discussion by Paul Hopkins, The Success of Mediation in the UK, in ADR Client Strategies in the UK: Leading Lawyers on Preparing Clients, Navigating the Negotiation Process, AND Overcoming Obstacles 145 (2008).

142 Civil Procedure Rules and Directions, pt. 44 (U.K.), available at http://www.justice.gov. uk/courts/procedure-rules/civil/pdf/parts/part44.pdf.

143 Rules of Civil Procedure, R.R.O. 1990, Reg. 194, r. 57 (Can.).
} 
award of costs typically decreases over time as legal fees continue to rise. Yet, since the nature of the rule remains informal and discretionary, litigants cannot fully rely upon its application when deciding whether or not to litigate. The decision to award costs is made at the conclusion of the action, which means a plaintiff still risks a substantial loss if the claim is ultimately unsuccessful.

"Both Australia and New Zealand follow the English civil rule ... unless the successful party has in some way behaved improperly in the course of the litigation."144 The same applies in Ireland where, as a general rule, the loser pays the costs. ${ }^{145}$ The right to an order in these circumstances is not absolute, however, and the court can exercise its discretion based upon the facts of the particular case. ${ }^{146}$

In contrast, in the United States each side generally bears its own costs, the so-called American rule. ${ }^{147}$ Notice that the English rule prevailed in the U.S. until the nineteenth century. ${ }^{148}$ The American rule was developed as lawyers gained the power to negotiate their contracts in a fairly unregulated framework. It became dominant by the 1850s. ${ }^{149}$ However, variants of a loser-pays-all rule still exist in federal civil procedure, namely Rule 68 of Federal Rules of Civil Procedure by which a party might have to reimburse the costs of the other party if the award is less than a rejected offer of settlement (a similar rule has been adopted in England and Wales after the Woolf reforms to civil procedure in 1996) ${ }^{150}$ In many cases, the court is allowed to order the losing side to pay the legal costs of the winner; however, this is often subject to the discretion of the judge. ${ }^{151}$

There is an extensive literature on the American versus English rule in civil litigation. There is no consensus in the theoretical literature concerning the overall effect of shifting litigation costs. ${ }^{152}$ The controversial topics include the extent to which shifting costs promote settlement, ${ }^{153}$ enhance

\footnotetext{
144 Ian Freckelton, Judicial Attitudes Toward Scientific Evidence: The Antipodean Experience, 30 U.C. DAVIS L. REV. 1137, 1142 (1997).

145 Melody Buckley, Civil Procedure AND Practice (2004).

146 Id.

147 LANGBEIN ET AL., supra note 30, at 1050.

148 Id.

149 Id.

150 HARRY WOOLF, ACCESS TO JUSTICE (1996), available at http://webarchive.nationalarch ives.gov.uk/+/http://www.dca.gov.uk/civil/final/contents.htm.

151 For some versions of fee-shifting in specific circumstances, see FED. R. CIV. P. 11(c)(4), 26(g)(3), 37, 41(d)(1).

${ }^{152}$ Hugh Gravelle, The Efficiency Implications of Cost-Shifting Rules, 13 INT'L REv. L. \& ECON. 3, 3 (1993); see also Ronald Braeutigam et al., An Economic Analysis of Alternative Fee Shifting Systems, 47 LAW \& CONTEMP. ProBs. 173, 181-82 (1984) (explaining that the glut of assumptions required by fee-shifting analysis make reaching clear conclusions difficult).

${ }^{153}$ Lucian Arye Bebchuk, Litigation and Settlement Under Imperfect Information, 15
} 
civil litigation, ${ }^{154}$ favor more meritorious claims or decrease the number of nuisance lawsuits. ${ }^{155}$ The results depend on asymmetric information, ${ }^{156}$ risk aversion, ${ }^{157}$ strategic positions ${ }^{158}$ and other procedural rules. ${ }^{159}$ The empirical and experimental literature does not seem to be conclusive. ${ }^{160}$

It is clear that the English rule tends to prevail in common law jurisdictions. ${ }^{161}$ The United States deviated from the general trend in the nineteenth century. ${ }^{162}$ The evolution of the rules concerning cost allocation could be a good example of multiple equilibria where the final outcome is determined by local determinants. The different structure of the legal markets, the practice of contingency fees (largely confined to the United States until recently), ${ }^{163}$ and the needs posed by different rates of growing civil litigation could easily determine the appropriate use of different rules. ${ }^{164}$

RAND J. ECON. 404, 404 (1984).

${ }^{154}$ Steven Shavell, Suit, Settlement, and Trial: A Theoretical Analysis Under Alternative Methods for the Allocation of Legal Costs, 11 J. LEGAL STUD. 55, 72 (1982) (explaining that British and American rules may interact with other factors to influence "social welfare relative to the goal of achieving an appropriate volume of litigation”).

${ }^{155}$ Lucian Arye Bebchuk \& Howard F. Chang, An Analysis of Fee Shifting Based on the Margin of Victory: On Frivolous Suits, Meritorious Suits, and the Role of Rule 11, 25 J. LEGAL STUD. 371, 372 (1996).

${ }^{156}$ Keith N. Hylton, An Asymmetric-Information Model of Litigation, 22 INT’L REV. L. \& ECON. 153 (2002).

157 Shavell, supra note 154, at 57-58.

158 Hylton, supra note 156, at 154.

159 Brian G.M. Main \& Andrew Park, The Impact of Defendant Offers into Court on Negotiation in the Shadow of the Law: Experimental Evidence, 22 INT'L REV. L. \& ECON. 177, 178 (2002) (noting the existence of procedural arrangements specifically designed to influence settlement that can influence the choice of cost-shifting rule); Jennifer F. Reinganum \& Louis L. Wilde, Settlement, Litigation, and the Allocation of Litigation Costs, 17 RAND J. EcoN. 557 (1986); John C. Hause, Indemnity, Settlement, and Litigation, or I'll Be Suing You, 18 J. LEgAL Stud. 157 (1989); Louis Kaplow, Shifting Plaintiffs' Fees Versus Increasing Damage Awards, 24 RAND J. ECON. 625 (1993); A. Mitchell Polinsky \& Daniel L. Rubinfeld, Optimal Awards and Penalties When the Probability of Prevailing Varies Among Plaintiffs, 27 RAND J. Econ. 269 (1996); A. Mitchell Polinsky \& Daniel Rubinfeld, Does the English Rule Discourage Low-Probability-of-Prevailing Plaintiffs?, 27 J. LEGAL STUD. 519 (1998).

160 Compare Edward A. Snyder \& James W. Hughes, The English Rule for Allocating Legal Costs: Evidence Confronts Theory, 6 J.L. Econ. \& ORG. 345, 377-78 (concluding that the English rule reduces overall litigation and encourages settlement), and Main \& Park, supra note 159, at 188 (concluding that the English rule has little impact on "propensity to settle"), with Brian G.M. Main \& Andrew Park, An Experiment with Two-Way Offers into Court: Restoring the Balance in Pre-Trial Negotiation, 30 J. Econ. STUD. 125, 139-40 (2003) (concluding that English rule may reduce settlement but ultimately has highly variable effects).

${ }^{161}$ Herbert M. Kritzer, Lawyer Fees and Lawyer Behavior in Litigation: What Does the Empirical Literature Really Say?, 80 TeX. L. REV. 1943, 1946 (2002).

${ }^{162}$ LANGBEIN ET AL., supra note 30, at 105.

163 Martin Davies, Time to Change the Federal Forum Nonconveniens Analysis, 77 TuL. L. REV. 309, 346 (2002).

164 The consideration of variants does not change the conclusions of our analysis. For 


\section{E. Civil Juries}

Whereas the United States continues to use of civil juries, their use has drastically declined over the past decades in the U.K., ${ }^{165}$ Australia, ${ }^{166}$ New Zealand, ${ }^{167}$ Canada, ${ }^{168}$ and Ireland. ${ }^{169}$ "Until the mid-nineteenth century, jury trial was the only form of trial in the common law courts, and until the early twentieth century, it continued to predominate for civil as well as criminal cases." ${ }^{170}$ The civil jury has largely disappeared in England and Wales, and the right to a jury in criminal cases has been significantly reduced as well. ${ }^{171}$ In the U.K. “[t]oday, less than one percent of civil trials are jury trials”; such trials are limited to cases of libel and slander, fraud, malicious prosecution, and false imprisonment as defined by the Supreme Court Act. ${ }^{172}$ However, even in these limited cases, the trial judge has the discretion to deny the right to a jury if the case is particularly complex. ${ }^{173}$ In Ward $v$. James, the Court of Appeal held that a single judge should hear all personal injury litigation unless there were special considerations. ${ }^{174}$

In England and Wales, civil juries are most frequently used in defamation cases. The frequent large awards decided by juries have been a matter of controversy. In 1995, the Court of Appeal in John v. MGN Ltd. ruled to curb

examples of such variants, consider Janice Toran, Settlement, Sanctions, and Attorney Fees: Comparing English Payment into Court and Proposed Rule 68, 35 AM. U. L. REV. 301, 304, 308 (1985-1986), citing U.S. Federal Rule 68 and the English practice of payment into court as rules that shift costs based on the failure to achieve settlement; or Bebchuk \& Chang, supra note 155, at 372, citing Federal Rule 11 as a rule shifting costs based on the margin of victory. Also, the fact that American states have variants of the English rule under some conditions; see for example Main \& Park, supra note 159, at 178 \& n.3, which does not undermine our conclusion.

165 Sally Lloyd-Bostock \& Cheryl Thomas, Decline of the "Little Parliament": Juries and Jury Reform in England and Wales, 62 LAW \& ConTEMP. PRoBs. 7, 7 (1999).

${ }_{166}$ Michael Chesterman, Criminal Trial Juries in Australia: From Penal Colonies to a Federal Democracy, 62 LAW \& ConTEMP. PRoBs. 69, 69 n.1 (1999).

167 Neil Cameron et al., The New Zealand Jury, 62 LAw \& ConTemp. Probs. 103, 138 (1999).

${ }^{168}$ W.A. Bogart, "Guardian of Civil Rights . . . Medieval Relic”: The Civil Jury in Canada, 62 LAW \& CONTEMP. PROBS. 305, 305 (1999).

169 John D. Jackson et al., The Jury System in Contemporary Ireland: In the Shadow of a Troubled Past, 62 LAW \& ConTEMP. PROBS. 203, 203 (1999).

170 Bostock \& Thomas, supra note 165, at 9.

${ }^{171}$ Neil Vidmar, A Historical and Comparative Perspective on the Common Law Jury, in WORLD JuRY SyStems 1, 7 (Neil Vidmar ed., 2000); Oscar G. Chase, American “Exceptionalism” and Comparative Procedure, 50 AM. J. CoMP. L. 277, 288-89 (2002).

172 Bostock \& Thomas, supra note 165, at 13; Marc Galanter, The Civil Jury as Regulator of the Litigation Process, 1990 U. CHI. LEgAL F. 201, 202 (1990) ("In England, a series of restrictions reduced the use of juries from 100 percent of civil trials in 1854 to two percent a century later.”).

173 Bostock \& Thomas, supra note 165, at 13.

174 Ward v. James, [1966] 1 Q.B. 273 (Eng.). 
excessive jury awards by altering jury instructions. ${ }^{175}$ The Defamation Act of 1996 further curtailed the role of juries in libel cases, establishing a summary procedure whereby judges, not juries, can dispose of libel claims up to $£ 10,000 .{ }^{176}$ The Court of Appeal has also issued guidelines on the directions given to juries assessing damages in cases of wrongful arrest and malicious prosecution brought against the police. ${ }^{177}$ Case law, reinforced by specific statute law, has essentially eliminated civil juries in the U.K. ${ }^{178}$

In Australia, civil juries are still available in all of the states except South Australia, but are rarely used outside New South Wales and Victoria. ${ }^{179}$ Furthermore, trial by jury in Australian civil matters has substantially declined in the last decades. ${ }^{180}$ Today, Australian judges decide the large majority of civil cases. ${ }^{181}$ It is rare, particularly following recent legislative reforms to tort law, for a jury to decide a civil case. ${ }^{182}$ In Australian jurisdictions without legislative mandates abolishing juries in civil actions, legislation "tends to allow the parties to opt for trial by jury . . . but maintains the court's discretion to control that choice."183 “[T]he courts have discretion to order jury trials for certain types of lawsuits, such as defamation, fraud, false imprisonment, malicious prosecution, and motor vehicle accidents.",184

175 [1997] Q.B. 586 (Eng.).

176 Defamation Act, 1996, c. 31, §§ 8-9.

177 Thompson v. Comm'r of Police of the Metropolis, [1997] 2 All E.R. 762 (Eng.).

178 Lewis N. Klar, The Impact of the U.S. Tort Law in Canada, 38 PEPP. L. REV. 359, 366 (2011); see also Senior Courts Act, 1981, § 69 (U.K.) (limiting trial by jury to judicial acknowledgement of a claim of fraud, libel, slander, malicious prosecution, or false imprisonment). Although the frequency of civil jury trials has been reduced, Scotland utilizes civil juries most frequently. Civil juries were abolished in the Sheriff Court, which is the lower of the civil courts. In the Court of Session, the higher civil court, some civil actions for personal injury damages and defamation are still tried by jury. Court of Session Act (1988) $\S 11$ (U.K.). Section 11 replaced its outdated counterpart in the Court of Session Act (1825) $\S 11$ (U.K.), and removed from the ambit of jury trial a large number of types of actions, which, in practice, never went to a jury. Peter Duff, The Scottish Criminal Jury: A Very Peculiar Institution, 62 LAW \& ConTEMP. ProBs. 173, 174 (1999).

179 Michael Tilbury \& Harold Luntz, Punitive Damages in Australian Law, 17 LoY. L.A. INT'L \& COMP. L.J. 769, 775-76 (1995).

180 S. Stuart Clark, Thinking Locally, Suing Globally: The International Frontiers of Mass Tort Litigation in Australia, 74 DEF. Couns. J. 139 (2007).

181 See, e.g., Tilbury \& Luntz, supra note 179, at 776 (stating "the majority of civil actions [in Australia] do not use juries”); Kylie Burns, The Role of the Judiciary: Passive or Active?, Legaldate, May 2006, at 4 ("Judges now decide the vast majority of court cases in Australia.”); Jacqueline Horan, Perceptions of the Civil Jury System, 31 MonASH U. L. Rev. 120, 120 (2005) (noting that "[t]here is an Australia-wide trend of reducing the right to civil jury trial”).

182 Burns, supra note 181.

183 Tilbury \& Luntz, supra note 179, at 775-76; see also Gerlach v Clifton Bricks Pty Ltd. (2002) 2009 CLR 478, 507 (Austl.) (disputing that civil jury trials cost more and take longer).

184 Lucille M. Ponte, Reassessing the Australian Adversarial System: An Overview of Issues in Court Reform and Federal ADR Practice in the Land Down Under, 27 SYRACUSE J. INT'L 
However, courts will rarely order a jury trial in strictly commercial disputes. ${ }^{185}$ Australian jury trials are "almost always reserved for more serious criminal matters." 186 The profound difference in the way the U.S. and Australia treat civil juries has been recognized by the literature. ${ }^{187}$

Civil juries are also rarely used in New Zealand. ${ }^{188}$ The Supreme Court Act of 1841 established a right to jury trial in all civil cases. ${ }^{189}$ In 1860, the Supreme Court ruled that parties could consent to having judges alone determine issues of fact. ${ }^{190}$ From 1862 to 1977, “minor jury sittings” (began with six jurors but shifted to four jurors prior to abolishment) were established for cases under $£ 100$ in value and were used at the discretion of the trial judge. ${ }^{191}$ Currently, the High Court provides the right to civil jury trial in most cases at the request of either party. ${ }^{192}$ Nevertheless, civil jury trials are so rare in practice that the Department for Courts no longer even keeps statistics on it. When implemented, civil juries are largely confined to defamation and personal injury cases, and are sometimes used in actions against governmental bodies. ${ }^{193}$ However, "New Zealand effectively abolished juries in personal injury cases in 1972 by adopting a no-fault compensation system that replaced litigation.”194 In New Zealand, we could

L. \& CoM. 335, 340 n.38 (2000).

${ }^{185}$ William Gummow, The Injunction in Aid of Legal Rights-An Australian Perspective, LAW \& CONTEMP. PROBS. 83, 85 (1993).

${ }^{186}$ Burns, supra note 181.

187 See, e.g., Gerald Walpin, America's Failing Civil Justice System: Can We Learn from Other Countries?, 41 N.Y.L. ScH. L. REV. 647, 652 (1997) (comparing the approach of Australian and American legal systems to civil jury trials very briefly); Caroline Forell, Statutes and Torts: Comparing the United States to Australia, Canada, and England, 36 WillametTe L. ReV. 865, 872 (2000) (noting that Australia appears to be headed in the direction of eliminating jury involvement in nearly all tort claims); Steven T. Masada, Australia's "Most Extreme Case": A New Alternative for U.S. Medical Malpractice Liability Reform, 13 PAC. RIM L. \& POL’y J. 163, 180, 193 (2004) (suggesting that the U.S. legal system should adopt several reforms modeled after the Australian legal system, including the Australian approach to civil juries: "Australia does not use civil juries and attorneys are compensated according to an hourly wage-two features that help reduce litigation, judicial backlog, and the high costs associated with the American civil system.”).

188 Cameron et al., supra note 167, at 103.

189 Supreme Court Act 1841, § 19 (N.Z.).

190 Supreme Court Act 1860, § 22 (N.Z.).

191 Supreme Court Act Amendment Act 1862, § 8 (N.Z.) ("The following classes of [c]ases may be tried at the "Minor Jury Sittings" ... [ [for] [i]nquiries of damages . . . not exceed[ing] One hundred pounds.”); id. § 10 ("At any such 'Minor Jury Sittings' ... the Judge presiding ... may try and decide any issue of fact which he is by law empowered to try."); id. $\S 12$ ("The Jury at such Sittings shall consist of six Jurors.”); Judicature Amendment Act 1977, § 9 (“Juries of 4 abolished.”).

192 Judicature Act 1908, §§ 19A, 19B (N.Z.).

193 Neil Cameron et al., The New Zealand Jury: Towards Reform, in WORLD JuRY SYsTEMS, supra note 171 , at $167,178$.

194 Scott Brister, The Decline in Jury Trials: What Would Wal-Mart Do?, 47 S. TEX. L. REV. 
say that there is still a theoretical right to a jury trial in civil cases, but such right is rarely used in practice. ${ }^{195}$

As with other common law jurisdictions, civil juries exist on the periphery in Canada. ${ }^{196}$ In some Canadian jurisdictions the use of civil juries has been highly curtailed while in other jurisdictions it has been outright abolished. ${ }^{197}$ Canadian courts retain the right to interfere with the judgment of a jury once it has reached a verdict; ${ }^{198}$ however, judges usually show great deference to the jury's verdict. ${ }^{199}$ Juries are most often used in motor vehicle accident litigation and are frequently sought by institutional parties. ${ }^{200}$ They are most prevalent in Ontario. ${ }^{201}$ Courts most often strike civil juries if the factual issues of a case are unduly complex. ${ }^{202}$ Additionally, the Supreme Court held in 1997 that judges have the discretion to determine whether to strike a civil jury if jurors can reasonably infer that a defendant was insured against a finding of liability. ${ }^{203}$

Civil jury trials have almost entirely disappeared in Ireland. ${ }^{204}$ In the Republic of Ireland, civil juries are retained only for libel, slander, assault, and false imprisonment cases; in Northern Ireland, civil juries are retained only for libel claims or if the judge accedes to a particular application. ${ }^{205}$ issues of causation and the likelihood of conflicting expert testimony); Taguchi v. Stuparyk [1993] A.J. No. 843 (Alta. Q.B.) (striking the jury because the trial would involve lengthy examination of documents and actuarial reports as well as much conflicting expert testimony).

${ }^{203}$ Hamstra v. British Columbia Rugby Union, [1997] 1 S.C.R. 1092, 1096 (Can.) (overturning Theakston v. Bowhey, [1951] S.C.R. 679, 683 (Can.), granting judges the discretion to release the jury if the jury can reasonably infer that a defendant is insured against a finding of liability); Thomas-Robinson v. Song, [1997] 34 O.R.3d 62 (Ont. Gen. Div.) (holding that the right to challenge potential jurors for cause, whether for racial bias or otherwise, does not exist in civil cases). While questions of law are rarely reserved for judges, Canadian courts often hold that complicated issues of law in a civil case are cause for striking the jury. See, e.g., MacDougall v. Midland Doherty Ltd., [1984] 48 O.R.2d 603 (Ont. H.C.J.) (striking jury); Fulton v. Fort Erie, [1982] 40 O.R.2d 235 (Ont. H.C.J.) (striking jury); Damien v. O’Mulvenny, [1981] 34 O.R.2d 448 (Ont. H.C.J.) (striking jury).

204 Jackson et al., supra note 169.

205 Id. at 203-04 \& n.3 ("The most significant recent change occurred when personal injury claims were taken out of the control of juries, first in Northern Ireland in 1987 and shortly
} 
It is clear that the U.S. has not followed the path of other common law jurisdictions in eliminating or drastically reducing the use of civil juries. ${ }^{206}$ In fact, legal scholars have suggested the advantages of following the Australian or the English models in the United States. ${ }^{207}$ The economic literature has considered the multiple implications of using civil juries, including legal certainty, the impact on awards, the development of procedural rules, and the potential additional litigation costs. ${ }^{208}$ Both at the theoretical and at the empirical level, it is unclear if the use of civil juries is economically efficient. ${ }^{209}$

More fundamentally, it is difficult to see how civil juries should be efficient in the United States but not in the other common law jurisdictions nowadays. It is clear that all common law jurisdictions initially had civil juries, and most have abandoned such institution because of legal costs and uncertainty. However, given the role of civil juries in the United States, it is unclear how the efficiency hypothesis could explain the different paths taken. It could be the case that the U.S. is behind the other jurisdictions in the evolutionary process, and so it is just a matter of time that civil juries are abolished in the United States. Such would be the most reasonable prediction under the efficiency hypothesis of the common law.

\section{CONCLUSIONS}

This Article has discussed the efficiency hypothesis of the common law from the perspective of comparative law. We argue that the general treatment of this hypothesis by legal economists leaves unanswered many

\footnotetext{
afterward in the Republic of Ireland in 1988.”).

206 Vidmar, supra note 171, at 3.

207 See Walpin, supra note 187, at 648-49.

208 See Neil Vidmar \& VAlerie P. Hans, American Juries 346 (2007) (concluding that, on balance, juries are adequate). For a more technical analysis, see Luke M. Froeb \& Bruce H. Kobayashi, Naive, Biased, Yet Bayesian: Can Juries Interpret Selectively Produced Evidence?, 12 J.L. Econ. \& ORG. 257 (1996).

209 Kevin M. Clermont \& Theodore Eisenberg, Trial by Jury or Judge: Transcending Empiricism, 77 CoRnell L. ReV. 1124 (1992); Neil Vidmar, The Performance of the American Civil Jury: An Empirical Perspective, 40 ARIZ. L. Rev. 849 (1998); Roselle Wissler et al., Decisionmaking About General Damages: A Comparison of Jurors, Judges, and Lawyers, 98 Mich. L. Rev. 751 (1999); Cass R. Sunstein et AL., Punitive Damages (2002); Joni Hersch \& W. Kip Viscusi, Punitive Damages: How Judges and Juries Perform, 33 J. Legal Stud. 1 (2004); Seth A. Seabury, Nicholas M. Pace \& Robert T. Reville, Forty Years of Civil Jury Verdicts, 1 J. EmPIRICAL LEgal Stud. 1 (2004); Margo Schlanger, What We Know and What We Should Know about American Trial Trends, 2006 J. DisP. Resol. 35; Theodore Eisenberg et al., Juries, Judges, and Punitive Damages: Empirical Analyses Using the Civil Justice Survey of State Courts 1992, 1996, and 2001 Data, 3 J. EMPIRICAL LEGAL STUD. 263 (2006).
} 
questions regarding the significant variations across the common law jurisdictions.

By making use of the mathematical models developed by legal economists to explain the efficiency hypothesis of the common law, we analyzed two different problems. First, there is not a single efficient rule or doctrine, but a multiplicity of possible equilibria depending on selective litigation. Second, for each specific set of selective litigation, there is no guarantee that there will be convergence to efficiency, depending on judicial attributes and the preponderance of precedent.

The identification of the efficiency of the common law is much more intricate and multifaceted than anticipated by the literature. A mere comparison of how a specific predicament is addressed in each jurisdiction, as inspired by the legal origins literature, is not only insufficient, but likely to produce gross mistakes. The observation that each jurisdiction provides a different legal outcome says very little about efficiency. First, there are multiple efficient legal solutions. Second, the variables that determine efficient outcomes vary significantly across the common law jurisdictions (England and Wales, U.S., Canada, Australia, New Zealand, and Ireland). A proper analysis requires a clear understanding of local determinants, including judicial preferences, before we can jump to the conclusion that the common law is undoubtedly efficient (or more precisely, which common law is undoubtedly efficient).

Our thesis has been illustrated with a detailed discussion of some relevant examples: tort law, defamation law, professional responsibility, allocation of costs in civil litigation, and civil juries. These examples are not exhaustive or suggested to be representative; they are merely good starting points for an important academic discussion. They show that once we depart from generalities into specific doctrines and rules, the analysis is complex, dense and less clear than the legal origins literature tends to portray. 